\title{
An ethnobotanical survey of edible fungi in Chuxiong City, Yunnan, China
}

\author{
Dongyang Liu ${ }^{1 \dagger}$, Hong Cheng ${ }^{1 \dagger}$, Rainer W. Bussmann², Zhiyong Guo ${ }^{1}$, Bo Liu ${ }^{1,3^{*}}$ and Chunlin Long ${ }^{1,4^{*}} \mathbb{D}$
}

\begin{abstract}
Background: Chuxiong, known as "the City of Fungi," is rich in fungal resources and traditional knowledge related to fungal biodiversity. The local environment is an excellent habitat for a wide variety of edible fungi. In addition, the region is home to many ethnic minorities and especially the Yi ethnic group who has a long history for traditionally using fungi as food or medicine. The aims of this review are to provide up-to-date information on the knowledge about, and traditional management of, fungi in this area and give advice on future utilization and conservation.
\end{abstract}

Methods: Field surveys and in-depth semi-structured interviews were used to gather data. Ethnomycological data was collected from 67 informants in the summer of 2015.

Results: Twenty-two edible fungal species were recorded both as food or non-timber forest products (NTFPs), used to increase income, and the importance of this resource for the Yi ethnic group was evaluated.

Conclusion: Abundant and diverse wild genetic resources and a large production chain of edible fungi were recorded in Chuxiong. However, because of over-harvesting, the wild edible fungi are facing increasing threats. Suggestions are proposed to allow sustainable use of fungi resources, including (1) promotion of diversification of transportation, (2) development of fungi cultivation to improve quality and supply and reduce harvest pressure, (3) improvement of public awareness for environmental protection and sustainable development, and (4) promotion of eco-tourism and development of fungi catering in rural agro- and slow-food tourism.

Keywords: Edible fungi, Market, Production chain, Sustainability, Ethnobotany

\section{Background}

Yunnan Province is located in the southwest part of China. This province harbors more than 15,000 plant species and is often called the "Kingdom of Plants" [1]. It has a wide variety of forest and soil types due to its unique natural mountainous environment [2,3], which also creates unique microclimates and ideal conditions for a wide variety of edible fungi. The edible fungi in Yunnan are well-known in the world, and production is large and widespread. Yunnan is one of the richest sources of edible fungi in China, which in itself has more than 600 species of edible fungi, $30 \%$ of the edible fungi species in the world [4]. The annual production amounts to about 50,000 $\mathrm{t}$, which does not include fungi from

\footnotetext{
* Correspondence: boliu@muc.edu.cn; long@mail.kib.ac.cn

${ }^{\dagger}$ Dongyang Liu and Hong Cheng contributed equally to this work.

${ }^{1}$ College of Life and Environmental Sciences, Minzu University of China,

Beijing 100081, China

Full list of author information is available at the end of the article
}

cultivation [5-7]. The production of edible fungi in Yunnan is the second largest agricultural export activity in the region. As a special industry, production of edible fungi is one of the important economic sources of the mountain areas [8]. With the growing emphasis on the conservation of biodiversity, the status and importance of the industry and fungi as a source for livelihoods become more and more prominent. Currently, there are about 15 million farmers working with edible fungi, and more than 400 factories process edible fungi, with more than 20 million people directly employed in the industry. Edible fungi in Yunnan are exported to 20 countries and regions, with Japan, the European Union, and the USA being the biggest traditional markets. South America, Africa, Russia, and ASEAN are the emerging markets [9]. The markets also show local differences, with, for example, Tricholoma matsutake (Chinese: 松茸; pinyin: song rong) mainly exported to Japan and Boletus

(C) The Author(s). 2018 Open Access This article is distributed under the terms of the Creative Commons Attribution 4.0 International License (http://creativecommons.org/licenses/by/4.0/), which permits unrestricted use, distribution, and 
(Chinese: 牛肝菌; pinyin: niu gan jun) and Morchella esculenta mainly exported to European countries.

The use and industrial production of edible fungi are ubiquitous in many areas around the globe, with distinct local characteristics. There are other regions rich in traditions of using edible fungi, such as Svaneti in Georgia, where 67 species of edible fungi were reported [10]. People living in Palas Valley, northeast Pakistan, like to eat Morchella esculenta (L.) Pers. (Chinese: 羊肚菌; pinyin: yang du jun) and use it as a part of their income source [11]. In Poland, 32 species of fungi were sold by local people in open-air markets [12]. There also are wild edible fungi found in other areas of China, but those areas do yet not count on an industrial production chain like we found in Chuxiong, Yunnan. Twenty-two fungi species were reported from Tewo County, Gansu, China, where people used to sell and store dried fungi [13]. In contrast, in Shaanxi, central China, few fungi species are traditionally used by local people, and production is not organized [14]. Only five taxa of edible fungi were recorded in Zhouqu County, Gansu, China. These edible fungi are however not harvested for commercial use [15]. Wild edible fungal resource development in Chuxiong relies mainly on collecting without paying and free trade. Most unemployed farmers in Chuxiong will take their children during summer vacation in July and August each year to pick wild edible fungi. During our survey in 2015, each household will earn around 1500 USD in this period, which provides positive social and financial benefits.

At present, China's edible fungi output ranks first in the world, and it has become an important industry in China [16]. However, due to the high economic value of fungi, over-harvesting is very common [17-19]. A lack of unified management leads to environmental degeneration, and wild edible fungal resources cannot get effective protection. Currently, production decreases year after year [20]. Tricholoma matsutake, Ophiocordyceps sinensis (Chinese: 冬虫夏草; pinyin: dong chong xia cao), Termitomyces albuminosus (Chinese: 鸡枞菌; pinyin: ji zong jun), and other famous wild edible fungi are gradually getting endangered in Chuxiong and other areas [21-23]. Therefore, wild collection needs to be combined with artificial cultivation based on the unique environment and climate conditions in Yunnan [24]. Moreover, yield and quality of edible fungi need to be improved, and local wild edible fungal resources need to be managed sustainably. The main aims of this study were (1) to record wild edible fungi species sold in the traditional markets of Chuxiong, (2) to gain insights into the local edible fungi industry chain, (3) to document associated ethnobotanical knowledge, and (4) to give some suggestions about the development of a more sustainable edible fungi industry chain and conservation of wild edible fungi.

\section{Methods}

\section{Study area and Yi people in Chuxiong}

Chuxiong City is located in the middle of Yunnan-Guizhou Plateau, west of Kunming, east of Dali, north of Pu'er, south of Panzhihua (Fig. 1). Its unique geographical location and climatic conditions create abundant plant resources. For example, wild edible fungi and wild herbs are very diverse in Chuxiong [25], with 540 species of fungi-90\% of all fungal species in Yunnan. Because of the plant worship, Yi people in Chuxiong are conducting traditional management of fungal ecosystems, and the local fungal habitats are well conserved before. With a long history of eating wild fungi, the local Yi people have accumulated rich traditional knowledge. However, with the development of society and the impact of the mainstream culture, traditional culture is gradually losing. And the wild edible fungi are faced with over-harvesting [26, 27]. Especially in recent years, fungi became more well-known as a homology of medicine and food; some local people try to harvest more fungus and sell to merchants to earn money. Our research team visited Chuxiong City to collect information on edible fungi, including species available, edible value [28-31], medicinal value [32], and market conditions, to gain in-depth knowledge about edible fungi and their trade.

With a population of 8.7 million, Yi is the sixth largest minority group in China and mainly distributed in Yunnan, Sichuan, and Guizhou Provinces and Guangxi autonomous region. They mainly inhabit mountainous areas or river valleys. Yunnan Province holds the largest population of the Yi nationality, around 4.06 million; the Yi ethnic group is one of the most complex groups with many branches with different traditional costume, culture, language, constructions, etc. [33].

Some scholars believe that the Yi ethnic group was formed by ancient Qiang people in northwest China around 6000-7000 years ago. At first, they were separated into six tribes due to different living conditions: Wu (Chinese: 武), Za (Chinese: 乍), Nuo (Chinese: 糯), Heng (Chinese: 恒), $\mathrm{Bu}$ (Chinese: 布), and $\mathrm{Mu}$ (Chinese: 慕), and then, they migrated to southwest China. Six major tribes settled down in different directions. Their languages evolved into six major language groups, and each language group has 30-50 dialects. People belonging to different major language groups cannot communicate with each other. And even people who are identified as one branch of Yi with same family names, after 7-11 generations, traditionally, they will hold a special event "Naimu (Chinese: 耐姆)" to give different families new family names, and this ceremony boosts the diversification of ethnic branch.

Chuxiong Yi Autonomous Prefecture is the largest residence of the $\mathrm{Yi}$ nationality and the largest $\mathrm{Yi} \mathrm{Au}$ tonomous Prefecture in the country. Due to historical 


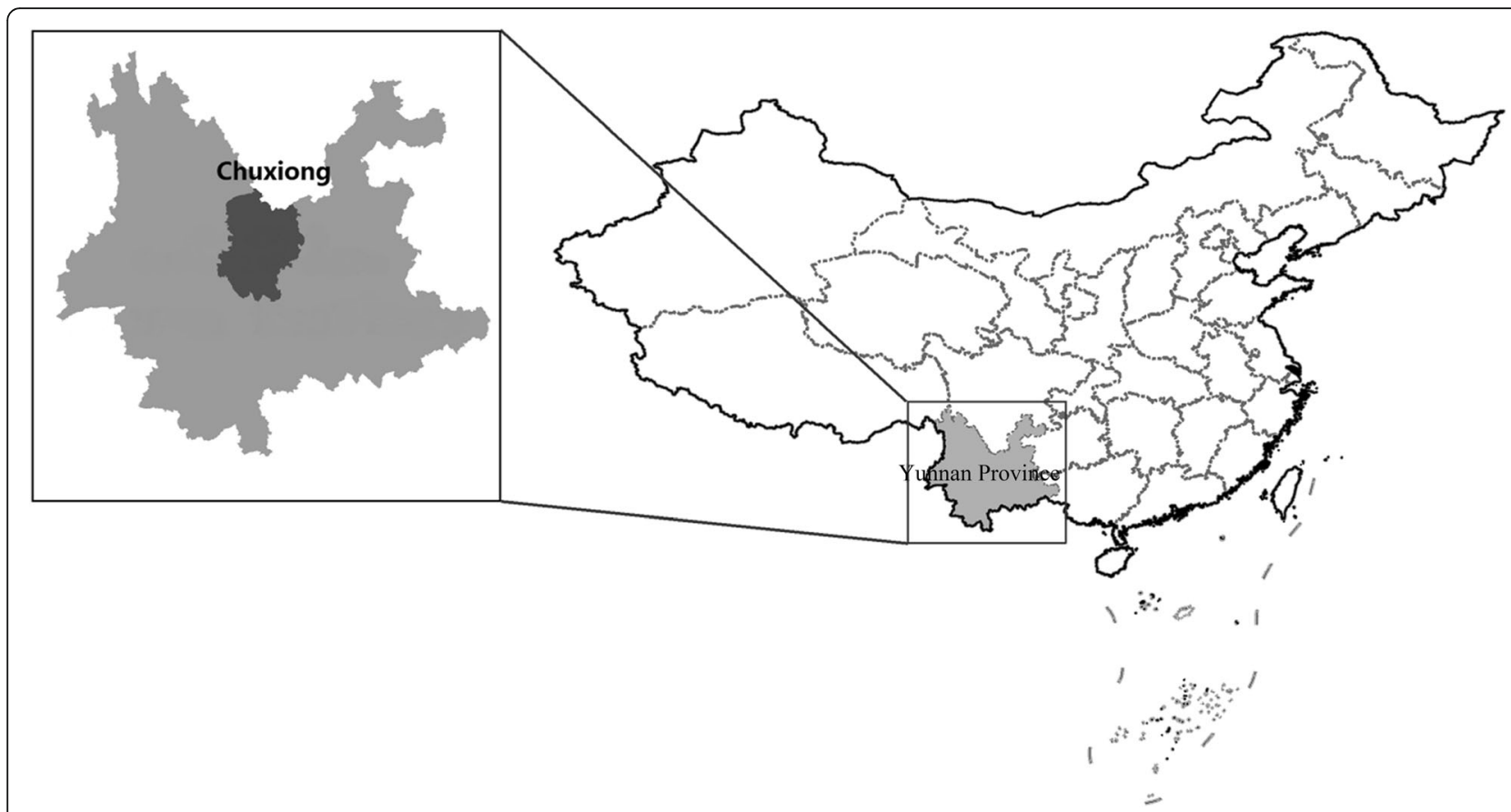

Fig. 1 The location of Chuxiong Yi Autonomous Prefecture, Yunnan, China

and geographical factors, Chuxiong has two Yi branches: $\mathrm{Wu}$ and $\mathrm{Za}$. And Yi people in Chuxiong call themselves Nousu (Chinese: 诺苏), Nasu (Chinese: 纳苏), and Niesu (Chinese: 聂苏). The study population was chosen from them. The Yi language belongs to the Yi Branch of the Tibeto-Burman Group of the Sino-Tibetan Language Family. It is divided into the Northern, Eastern, Southern, Southeastern, Western, and Central dialects now. Each dialect is also divided into many local dialects, and it is very difficult to communicate with each other using different dialects [34-36]. The interviewed Yi people in Chuxiong speak Central Yi dialects [37].

As base for our study, we consulted the literature to assess the current situation of local edible fungi and the growing season of local wild edible fungi [38-41]. Fieldwork was conducted in summers of 2008 and 2015. The surveys were carried out in three counties of Chuxiong Prefecture: Wuding, Nanhua counties, and Chuxiong City. We investigated six different sizes of wild edible fungi markets in Chuxiong, and the large markets include "wild edible fungi wholesale market of Nanhua, Chuxiong", "Chuxiong wholesale market of center agricultural products" and "wild edible fungi trading center of Kangzhao, Wuding." The edible wild fungi trading center in Wuding is the most representative market, which is surrounded by numerous Yi villages (such as Xiaofakuai, Dafakuai, Limi, Jijiezi, and Fawo). These Yi villages are surrounded by mountains. Because of the moderate climate, plentiful rainfall, and fertile soil, these mountains (such as Taishan, Daheishan, Wozhangshan,
Qiaoshan, Jidanshan, and Luoshan) are suitable for the growth of wild edible wild fungi. During the harvest period of wild edible fungi, unemployed farmers who pick fungi would have trade at the market. These wild edible fungi would be purchased by local Yi people or exported to other places.

\section{Ethnomycological research methods}

Semi-structured interviews were carried out with local people in order to document the fungal species, edible value, medicinal value, and market transactions. The interview locations include villagers' homes, edible fungi markets (including individual fixed purchase and food market), pine forest, and dehydrated edible fungi processing factory. Chuxiong is surrounded by mountains, and it is a long distance between countries because of continuous mountain roads. It is necessary to find local Yi guides to lead us to the interview locations. A total of 67 informants including 40 men and 27 women, all from Yi ethnic groups, with a large majority of middle-aged and younger people, were interviewed. Key informants included local guides, drivers, and five people collecting edible fungi as their career. All interviews were conducted after obtaining the oral prior informed consent of the individual participants. Usually Tibetans and Yi have the tradition of collecting mushrooms, and $\mathrm{Yi}$ people consume more mushroom, so most of the sellers and local customers are Yi people; of course, many overseas customers can get fresh mustache and other mushrooms in their own country. 
Table 1 Fungal species found and their usages

\begin{tabular}{|c|c|c|}
\hline Scientific name & $\begin{array}{l}\text { Vernacular name } \\
\text { (pinyin/Chinese/Yi) }\end{array}$ & $\begin{array}{l}\text { Habitat } \\
\text { characteristics }\end{array}$ \\
\hline $\begin{array}{l}\text { Agaricus silvicola (Vittad) } \\
\text { Peck. (Agaricaceae) }\end{array}$ & $\begin{array}{l}\text { san juer } \\
\text { 伞菌 }\end{array}$ & $\begin{array}{l}\text { Forest, grow } \\
\text { alone or in a } \\
\text { small group }\end{array}$ \\
\hline $\begin{array}{l}\text { Lactarius deliciosus (L.) } \\
\text { Gray (Agaricaceae) }\end{array}$ & $\begin{array}{l}\text { mao cao jun } \\
\text { 茅草菌 }\end{array}$ & $\begin{array}{l}\text { Grow in pine } \\
\text { forest }\end{array}$ \\
\hline $\begin{array}{l}\text { Vascellum pratense (Pers.) } \\
\text { Kreisel (Agaricaceae) }\end{array}$ & $\begin{array}{l}\text { ma pi pao } \\
\text { 马皮泡 }\end{array}$ & $\begin{array}{l}\text { Grow alone, in } \\
\text { grassy areas, } \\
\text { forest edges }\end{array}$ \\
\hline $\begin{array}{l}\text { Sarcodon imbricatus (L.) } \\
\text { P. Karst. (Bankeraceae) }\end{array}$ & $\begin{array}{l}\text { hu zhang jun } \\
\text { 虎掌菌 }\end{array}$ & $\begin{array}{l}\text { Grow in forest } \\
\text { with humic soil }\end{array}$ \\
\hline
\end{tabular}

Boletus luridus Schaeff. (Boletaceae)

jian shou qing 见手青

Boletus edulis Rostk (Boletaceae) [47]

Cantharellus cibarius $\mathrm{Fr}$. (Cantharellaceae)

Yi: va cy hmu

Ophiocordyceps sinensis (Berk.)
G.H. Sung et al. (Clavicipitaceae)

Ramaria botrytis (Pers.)

Ricken (Gomphaceae)

Ramaria madagascariensis (Henn.) Corner (Gomphaceae)

Helvella atra Oeder

(Helvellaceae)

Hericium erinaceus (Bull.) Pers. (Helvellaceae)

Termitomyces albuminosus (Berk.) Heim (Lyophyllaceae) chong cao

虫草 Yi: se ge bbup ddi

$\begin{array}{ll}\text { shua ba jun } & \text { Forest, grow } \\ \text { 刷把菌 } & \text { alone }\end{array}$ sao ba jun 扫把菌

pi tiao jun 皮条菌

yang mao jun 羊毛菌 Yi: nyut o hmu

\section{ji zong jun} 鸡枞菌 a small group

Grow clustered

or scattered in forests

Grow on the top of trees

Have symbiotic relationship with
Termitomyces microcarpus (Berk et Brome) R. Heim (Lyophyllaceae)
Forest edges, grow alone or in a small group

Broad-leaved forest, grow alone or in a small group

Grow in forest of north temperate zone [50]

Coniferous forest, grow alone or in termite nests, grow in broadleaved and coniferous forest

huo ba ji zong 火把鸡枞

Have symbiotic relationship with termite nests, grow in groups

Rich in unsaturated fatty acids

Rich in proteins, crude fiber, unsaturated fatty acids, nucleic acid derivatives, vitamins $B 1$, B2, vitamin C [45]

Rich in proteins, amino acids, minerals, and polysaccharides [46]

Rich in polysaccharides, Alleviate cold symptoms [49]. Harvest time: summer choline) putrescine sterols [48]

Rich in proteins, fats, carbohydrates, vitamins, carotene, crude fiber, phosphorus, and a variety of mineral nutrients [51]

Rich in mannitol, SOD, and polysaccharides

Anti-cancer, anti-tumor nourish lungs, and regulate breath. Harvest time: spring Edible, delicious taste, nourish s.n. the stomach, anti-cancer. Harvest time: summer, autumn

Edible, delicious taste. Harvest s.n. time: summer, autumn

Prevent pernicious anemia, s.n. improve neurasthenia, cholesterol-lowering. Harvest time: summer, autumn

Anti-ulcer, anti-inflammatory, Y-M-061 anti-tumor, protect liver, strengthen immunity, antiaging, and enhance blood circulation. Harvest time: spring, summer, autumn

Rich in proteins, crude fat, crude fiber, and a variety of mineral nutrients [52]

Improve immune system, improve sleep. Harvest time: summer, autumn

Rich in proteins [53]

Protect stomach. Harvest s.n. time: summer, autumn

S.n.

Y-M-069

Y-M-068

Y-M-058

Y-M-062

Y-M-064

Clean liver, improve vision, regulate breath. Harvest time: summer

Y-M-070

nourish lungs, and regulate of specimens (n) 
Table 1 Fungal species found and their usages (Continued)

\begin{tabular}{|c|c|c|c|c|c|}
\hline Scientific name & $\begin{array}{l}\text { Vernacular name } \\
\text { (pinyin/Chinese/Yi) }\end{array}$ & $\begin{array}{l}\text { Habitat } \\
\text { characteristics }\end{array}$ & $\begin{array}{l}\text { Main chemical } \\
\text { components }\end{array}$ & $\begin{array}{l}\text { Nutritional and } \\
\text { medicinal value }\end{array}$ & $\begin{array}{l}\text { Accession number } \\
\text { of specimens }\end{array}$ \\
\hline $\begin{array}{l}\text { Morchella esculenta (L.) Pers. } \\
\text { (Morocellaceae) [54] }\end{array}$ & $\begin{array}{l}\text { yang du jun } \\
\text { 羊肚菌 } \\
\text { Yi: yo qy tie hmu }\end{array}$ & $\begin{array}{l}\text { Grow in } \\
\text { coniferous forests } \\
\text { and broad-leaved } \\
\text { forests }\end{array}$ & $\begin{array}{l}\text { Rich in vitamin B1, B2, } \\
\text { B12 [55] }\end{array}$ & $\begin{array}{l}\text { Protect stomach, nourish the } \\
\text { lungs, and strengthen } \\
\text { immunity. Harvest time: } \\
\text { spring, summer, autumn }\end{array}$ & Y-M-067 \\
\hline $\begin{array}{l}\text { Phallus indusiatus Vent. } \\
\text { (Phallaceae) }\end{array}$ & $\begin{array}{l}\text { zhu gu niang } \\
\text { 竹姑娘 }\end{array}$ & $\begin{array}{l}\text { Grow in hot and } \\
\text { humid areas }\end{array}$ & $\begin{array}{l}\text { Rich in proteins, crude } \\
\text { fat, and crude fiber [56] }\end{array}$ & $\begin{array}{l}\text { Nourish lungs and regulate } \\
\text { breath, improve sleep, } \\
\text { strengthen immunity. Harvest } \\
\text { time: autumn }\end{array}$ & Y-M-066 \\
\hline $\begin{array}{l}\text { Lactarius volemus (Fr.) Fr. } \\
\text { (Russulaceae) }\end{array}$ & $\begin{array}{l}\text { nai jiang jun } \\
\text { 奶浆菌 }\end{array}$ & $\begin{array}{l}\text { Grow in conifer } \\
\text { mixed forest }\end{array}$ & $\begin{array}{l}\text { Rich in a variety of } \\
\text { essential amino acids, } \\
\text { protein, fat, vitamins, } \\
\text { and a variety of } \\
\text { mineral nutrients [57] }\end{array}$ & $\begin{array}{l}\text { Anti-cancer, lower blood } \\
\text { pressure, protect liver, } \\
\text { detoxifying, diuresis. Harvest } \\
\text { time: spring, summer, autumn }\end{array}$ & s.n. \\
\hline $\begin{array}{l}\text { Russula virescens (Schaeff.) } \\
\text { Fr. (Russulaceae) [58] }\end{array}$ & $\begin{array}{l}\text { qing tou jun } \\
\text { 青头菌 }\end{array}$ & $\begin{array}{l}\text { Grow in mixed } \\
\text { forest }\end{array}$ & & $\begin{array}{l}\text { Protect liver, protect eyesight. } \\
\text { Harvest time: summer, } \\
\text { autumn }\end{array}$ & s.n. \\
\hline $\begin{array}{l}\text { Russula nitida (Pers.) Fr. } \\
\text { (Russulaceae) [59] }\end{array}$ & $\begin{array}{l}\text { xiao hong jun } \\
\text { 小红菌 } \\
\text { Yi: zzit hmu }\end{array}$ & $\begin{array}{l}\text { Grow in broad- } \\
\text { leaved forest, } \\
\text { solitary or in } \\
\text { groups }\end{array}$ & & $\begin{array}{l}\text { Harvest time: summer, } \\
\text { autumn }\end{array}$ & s.n. \\
\hline $\begin{array}{l}\text { Sparassia crispa (Wulfen) } \\
\text { Fr. (Sparassidaceae) }\end{array}$ & $\begin{array}{l}\text { hua er xiu qiu jun } \\
\text { 花饵绣球菌 }\end{array}$ & $\begin{array}{l}\text { Grow in } \\
\text { mountains, pine } \\
\text { forest, central and } \\
\text { western of } \\
\text { Yunnan }\end{array}$ & & $\begin{array}{l}\text { Anti-aging, cholesterol- } \\
\text { lowering, anti-cancer, } \\
\text { strengthen immunity. } \\
\text { Harvest time: summer }\end{array}$ & Y-M-059 \\
\hline $\begin{array}{l}\text { Stropharia rugosoannulata } \\
\text { Farl. ex Murrill (Sparassidaceae) }\end{array}$ & $\begin{array}{l}\text { zhou huan qiu gai } \\
\text { gu } \\
\text { 皱环球盖菇 }\end{array}$ & $\begin{array}{l}\text { Grow in forest } \\
\text { edges, grassy } \\
\text { areas, gardens, } \\
\text { garbage dumps, } \\
\text { sawdust pile, } \\
\text { cattle dunghill }\end{array}$ & $\begin{array}{l}\text { Rich in vitamins and } \\
\text { a variety of mineral } \\
\text { nutrients [60] }\end{array}$ & $\begin{array}{l}\text { Nourish brain. Harvest time: } \\
\text { spring, summer, autumn }\end{array}$ & s.n. \\
\hline $\begin{array}{l}\text { Tricholoma matsutake } \\
\text { (S. Ito et S. Imai) Singer } \\
\text { (Tricholomataceae) }\end{array}$ & $\begin{array}{l}\text { song rong } \\
\text { 松茸 } \\
\text { Yi: te hmu }\end{array}$ & $\begin{array}{l}\text { Grow in natural } \\
\text { forests without } \\
\text { any pollution and } \\
\text { human } \\
\text { intervention }\end{array}$ & $\begin{array}{l}\text { Rich in proteins, } \\
\text { vitamins, and a variety } \\
\text { of mineral nutrients } \\
\text { [61] }\end{array}$ & $\begin{array}{l}\text { Strengthen immunity, anti- } \\
\text { cancer, anti-aging, prevent } \\
\text { cardiovascular disease, } \\
\text { improve gastrointestinal } \\
\text { function, protect liver. } \\
\text { Harvest time: summer }\end{array}$ & Y-M-063 \\
\hline
\end{tabular}

Each survey documented the local name, frequency of use, and other values of the edible fungi held by informants. To understand the local wild edible fungi conditions and environment, we also assessed the local market share of various edible fungi, in order to make better recommendations for a more sustainable use of the resource. We collected 2-3 specimens for each species, total of 51 specimens, which were deposited at Minzu University of China (Beijing) and Kunming Institute of Botany herbaria. The specimens were later verified by the local Yi people in the market, authors, plant taxonomists, and experts from the authors' institution.

The collected ethnobotanical data of edible fungi included scientific name, local name, and information about the production chain. Scientific name, local name in Chuxiong, habitat characteristics, main chemical components, and nutritional and medicinal value were recorded for each edible fungi species in Table 1 .

\section{Results and discussion}

Our study found 22 species of edible fungi, which are most gathered from markets and a few collected from the wild (Fig. 2). These edible fungi are also mentioned by participants. These species were most frequently used by local people in summer and autumn. Most interviewees (39 villagers) said they had sold wild edible fungi to a purchasing company. This could increase their income but also increase the consumption of wild edible fungi, and over-harvesting might cause ecological damage. Some species mentioned in literature we did not encounter in the surveys.

Chinese name, pinyin, and Yi names have been listed in Table 1. Among the 22 species investigated, most interviewees know around 18-20 species' Chinese name and pinyin. Only 15 interviewees out of 67 know Yi names for 1-5 species. Sparassia crispa and Stropharia rugosoannulata are rarely seen. Although 50\% of 


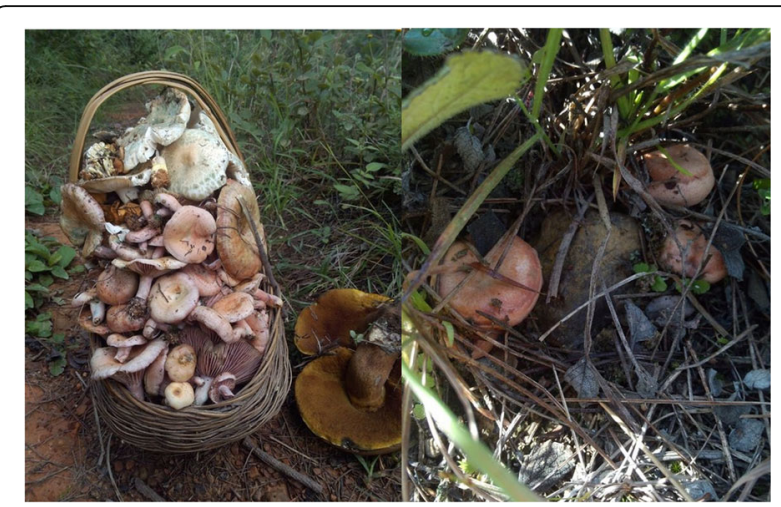

Fig. 2 Field collection of fungi in Chuxiong

interviewers know they are edible, only seven of them know exactly the Chinese common names.

\section{The current status of wild fungi}

Generally, wild fungi in Chuxiong mainly grow in coniferous forest, composed by Pinus yunnanensis and Pinus densata, or mixed forests. Different vegetation types and different geographical environments result in a wide diversity of wild fungi.

In our investigation, the most common edible fungi were Boletus edulis Rostk., Termitomyces albuminosus (Berk.) Heim, Morchella esculenta (L.) Pers., Phallus indusiatus Vent., and Tricholoma matsutake (S. Ito et S. Imai) Singer. They were largely supplied to domestic and foreign markets.

According to interviews, a household could earn around 1500 USD by selling mushrooms during the harvest period, which improves the living standards of the local people. However, the mushroom resources are limited, and the local villagers did often collect indiscriminately. For example, when they found small Termitomyces albuminosus (Berk.) Heim, they would cover it with pine needles. Then, they would to dig it when it grew and protect the mycelium so that the fungi could continue to grow. This ensured both the development of ecological sustainability and the sustainability of their income.

Because more and more factories were built in recent years, demanding more prime material, some sensitive fungi species are decreasing. Old people indicated there were a lot of Boletus edulis Rostk. before, but now, the villagers indicated the need to climb to higher altitudes to find the resource. Wild Tricholoma matsutake (S. Ito et S. Imai) Singer, one of the most famous edible fungi in the world, is becoming very scarce and hard to find in the field. It is thus essential to protect the environment to also protect the local industry chain.

In Nanhua County, the "Mushroom Food Culture Festival" is held every year and has been held for 14 sessions so far. Nanhua County proved to be especially rich for mushroom diversity, in our research.

This county is located in the western part of the Chuxiong Yi Autonomous Prefecture, in a high elevation area. The climate is dominated by the subtropical monsoon. The local environment is highly suitable for fungi. Tricholoma matsutake exports account for a large share of production, and "Nanhua Tricholoma matsutake" is protected by the National Protection of Geographical Indications. The annual income from wild edible fungi amounted to $7677 \mathrm{t}$, valued at 80 million USD.

\section{Conservation of fungi based on traditional management of Yi people}

The local Yi ethnic group in Chuxiong have over time developed a profound knowledge for utilizing edible fungi and developed their own management of ecosystem. Local people traditionally use edible fungi for food, medicine, religious worship, and culture, and Chuxiong conserves the highest fungal diversity in Yunnan. The reason could be attributed to the Yi minorities maintaining their customs of the utilization and management of local fungi diversity [42]. It is thus very important to utilize indigenous cultural knowledge for ecological and environmental conservation. We learned from the interviews that local people harvest wild edible fungi without destroying their hyphae. However, nowadays, with increasing loss of traditional culture, young harvesters prefer to simply uproot the fungi. For that reason, we suggest that the indigenous resource management knowledge and culture diversity should be conserved and extensively studied.

Chuxiong is becoming more and more commercialized, and the famous rich fungi resources and unique Yi traditional culture have become a famous destination for eco-tourists. This creates a complex relationship between traditional and modern management.

\section{Edible fungi industry chain}

In our research region, factories that produce dried edible fungi were generally built on hillsides, close to collectors' villages (Figs. 3 and 4). This has several advantages: (1) land is cheap, (2) it is convenient to purchase fresh edible fungi from the market when close to the village, and (3) it is convenient to transport when close to the road.

During our visit, we also investigated the local wild fungi production chain (Fig. 5). The Tricholoma matsutake industry, as example, allows to illustrate all aspects of the fungal production and trade. The Yunnan Tricholoma matsutake industry chain is composed of farmers, middlemen, manufacturers, and distributors (Fig. 6). The upstream production chain comprises mostly farmers, producing, breeding, 


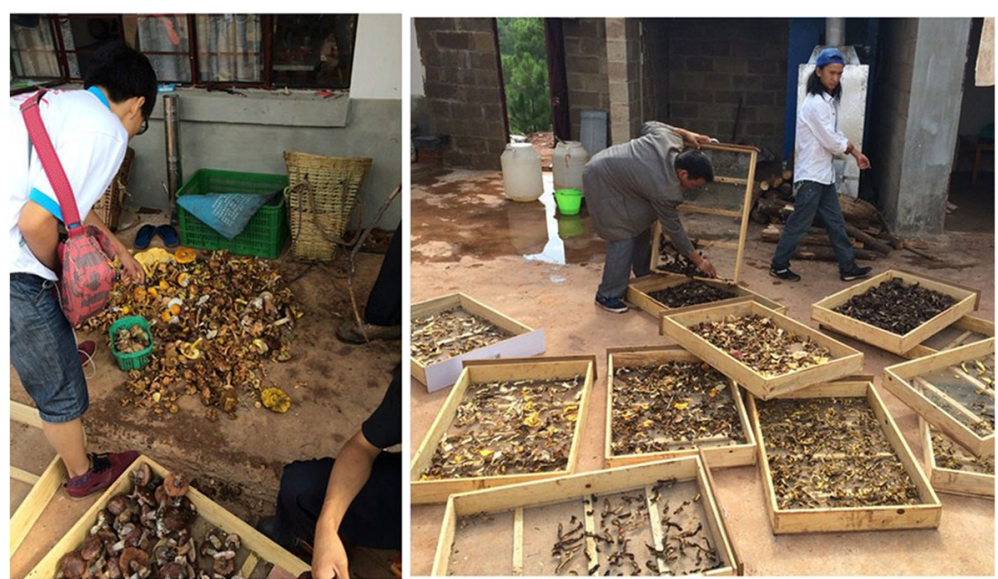

Fig. 3 The processing of dried edible fungi

picking, and primary packaging the resource. The midstream are middlemen, linking farmers to manufacturers and distributors. The number of middlemen is directly related to the transaction costs and efficiency. Downstream production includes manufacturers and distributors.

The Yunnan Tricholoma matsutake production chain is short and resource-based. The resource appears over-exploited and growingly endangered, threatening mountain farmers' income. To develop the Yunnan Tricholoma matsutake production chain under a concept of sustainability is of paramount importance.
The key factor in the development of the production chain of Yunnan Tricholoma matsutake is supply capacity and consumer demand. The demand for Yunnan Tricholoma matsutake is increasing, and the quality of the product, as well as supply capacity, has become a priority. However, the farmers, due to scattered and small-scale production, provide relatively low-quality material. The lack of the ability to control the market and other factors becomes a bottleneck of product supply. Industrial management through enterprise groups tries to unite the large number of scattered farmers to achieve continuous supply. Moreover, collectivization,
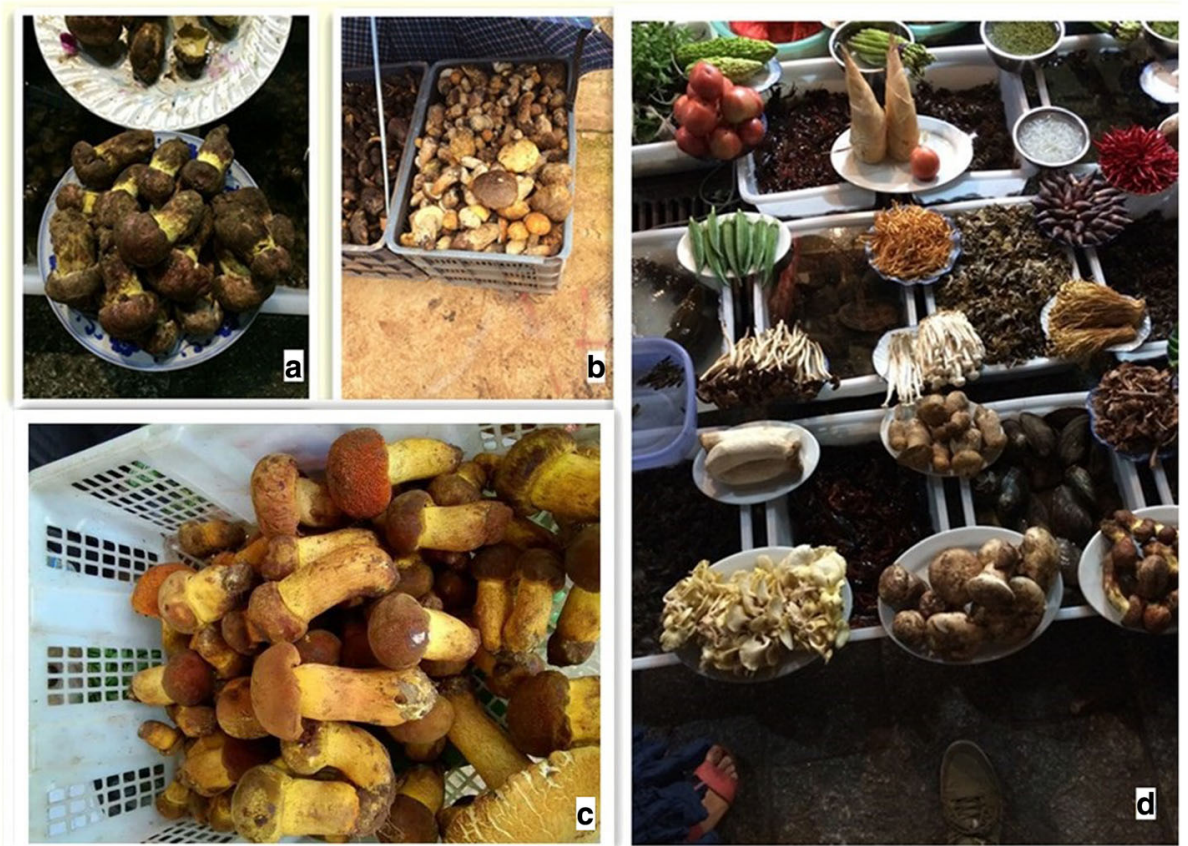

Fig. 4 a, b The most common edible fungus: Boletus edulis Rostk. (Chinese: 美味牛肝菌; pinyin: mei wei niu gan jun). c The most common edible fungus: Boletus calopus Fr. (Chinese: 美柄牛肝菌; pinyin: mei bing niu gan jun). d A variety of edible fungi shown in a restaurant 


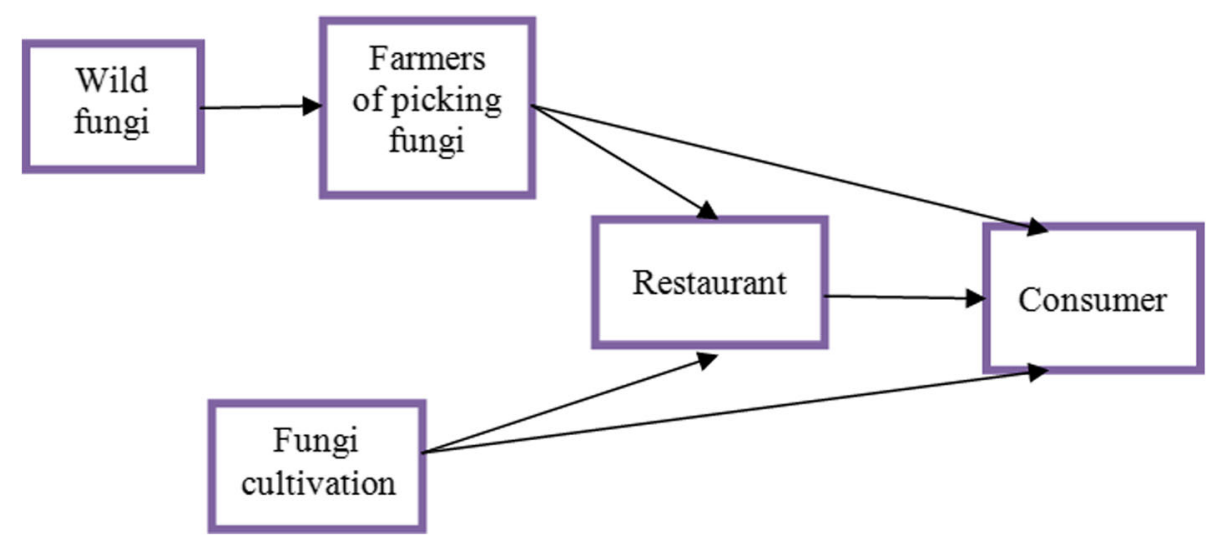

Fig. 5 The main production chain of edible fungi

and large-scale development, can closely link all aspects of the production chain and promote the flow of technology, capital, and other factors to extend the production chain. Members of this production group found that the Yunnan Tricholoma matsutake production chain is currently in its infancy, characterized by low-tech production and the lack of strong competitiveness. Therefore, we recommended to use the power of government departments to improve the industrial management of Yunnan wild edible fungi. Local government should increase financial input and establish industrial cooperation organization systems to create an even wider market according to the scientific planning. Because the resources of wild edible fungi are limited, local government should encourage more famers to engage in the cultivation of edible fungi to ensure the sustainable development [43].

In Beijing, we found Termitomyces albuminosus (Berk.) Heim and Boletus edulis Rostk. made into snacks and sold in the large supermarkets. Morchella esculenta (L.) Pers.,

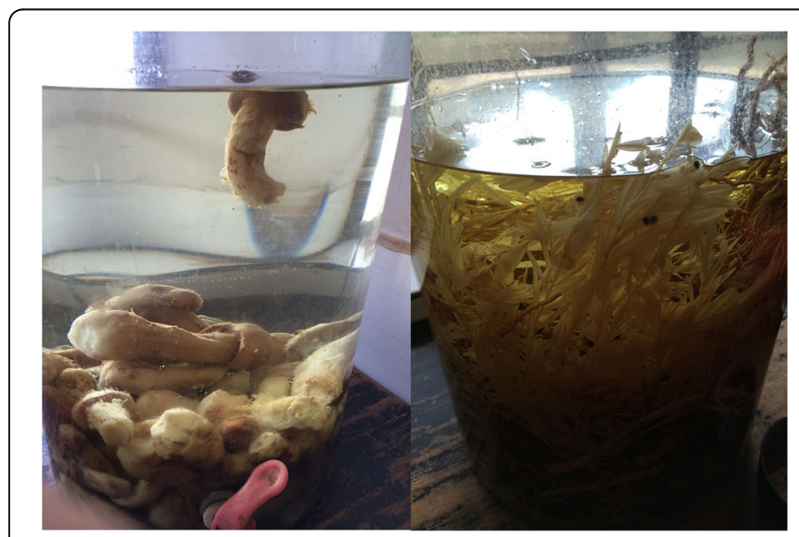

Fig. 6 Ophiocordyceps sinensis (Berk.) G.H. Sung et al. and Tricholoma matsutake (S. Ito et S. Imai) Singer steeped in liquor
Phallus indusiatus Vent. and Tricholoma matsutake (S. Ito et S. Lmai) Singer are dried for sale. Some fungi, such as fresh Cantharellus cibarius Fr. and Helvella atra Oeder are however not easily preserved and thus difficult to produce in an industrial chain.

\section{Conclusions}

Our study provides ethnomycological data on the wild edible fungi in Chuxiong, Yunnan. Twenty-two wild edible fungi are found used for traditional food by Yi people, which are more than other countries in China but less than Tshopo Province in the Democratic Republic of the Congo [13-15, 44]. However, the commercialization of wild edible fungi in Chuxiong is more advanced because of the support by government, including holding the "Mushroom Food Culture Festival" and building the well-developed road network. Wild edible fungi are traditional food for the Yi people. Due to economic development, wild edible fungi have become much commercialized, and while the fungal industry chain has boosted the local economy, it has also created some unexpected social and ecological problems. Due to the medicinal value of wild edible fungi, local people in Chuxiong even used Ophiocordyceps sinensis (Berk.) G.H. Sung et al. and Tricholoma matsutake (S. Ito et S. Imai) Singer to be steeped in liquor (Fig. 6). Through this investigation, we propose the following suggestions for promoting local edible fungi development and rural development:

(1) Promote the diversification of transportation. Due to easy spoilage, edible fungi are normally transported dry, rather than fresh. The development of air transport systems has been approved by the Yunnan government, which would be helpful expand the markets of edible fungi. Also, it can reduce the loss in transit. 

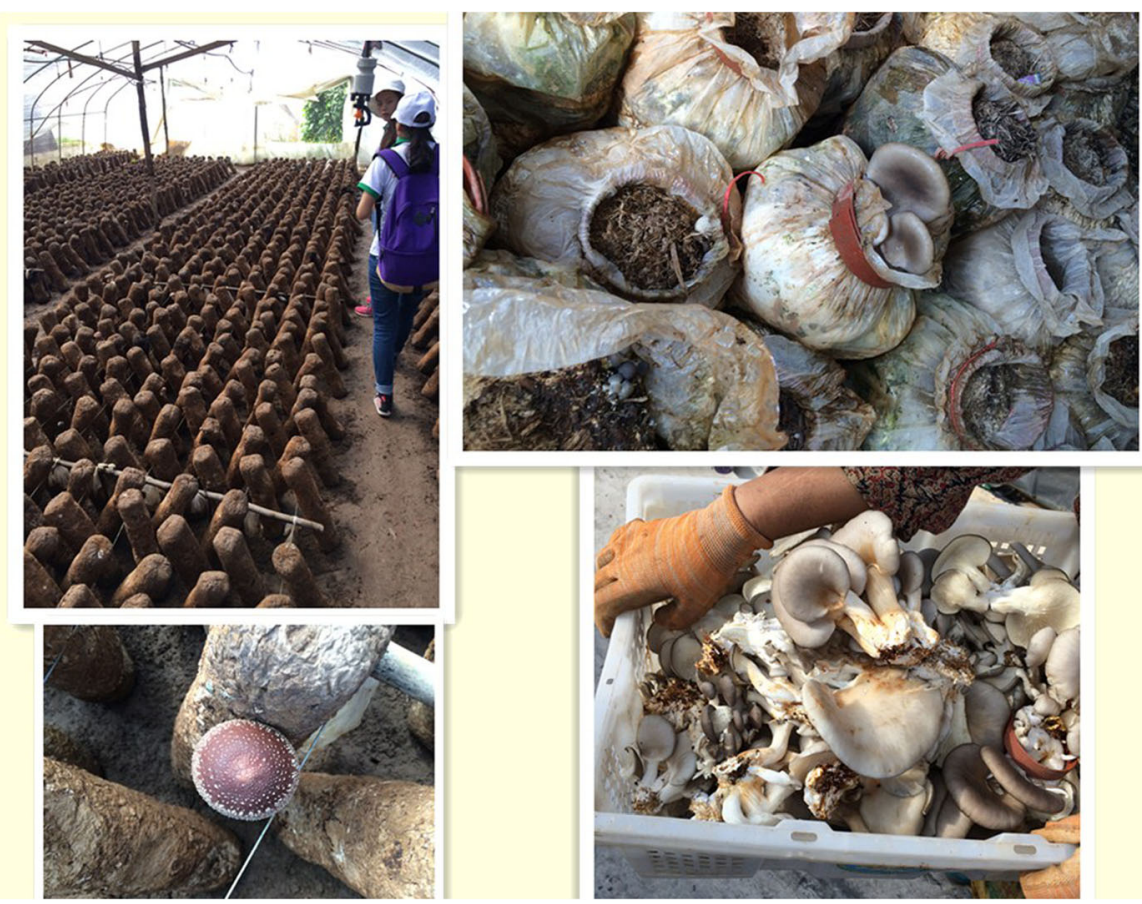

Fig. 7 Industrial production of fungi

(2) Develop cultivation of fungi to improve quality and supply and reduce harvest pressure (Fig. 7).

(3) Improve the public awareness of environmental protection and promote sustainable development. Over-exploitation is detrimental to economic development and threatens the survival and development of future generations.

(4) Promote eco-tourism and develop fungi catering in rural agro- and slow-food tourism. Edible fungi are very popular, but awareness about possible threats and conservation issues is limited. It is necessary to build brands, if the government wants to develop the edible fungi industry in the future.

\section{Acknowledgements}

We thank the villagers who accepted to be interviewed and helped us in our work. Moreover, we appreciate the funding received from the Social Practice Program for University Students in Minzu University of China and the National Natural Science Foundation of China (31761143001, 31161140345, 31400182), China Scholarship Council, and Minzu University of China (2015MDTD16C, ydzxxk201618)

\section{Funding}

Funding was recieved from the National Natural Science Foundation of China (31761143001, 31161140345, 31400182), China Scholarship Council, and Minzu University of China (2015MDTD16C, YLDXXK201819).

\section{Availability of data and materials}

Raw data can be requested from the corresponding author.

\section{Authors' contributions}

$\mathrm{BL}$ and $\mathrm{CL}$ conceived the study. DL, HC, and ZG conducted the interviews. $B L$ and $C L$ identified fungal species. $D L$ and $H C$ analyzed the data. $D L, H C$,
$R B, Z G, B L$, and $C L$ wrote the manuscript. $C L, B L, R B, D L, H C$, and $Z G$ edited the manuscript. All authors read and approved the final manuscript.

Ethics approval and consent to participate

All participants were asked for their free prior informed consent before interviews were conducted.

\section{Competing interests}

The authors declare that they have no competing interests.

\section{Publisher's Note}

Springer Nature remains neutral with regard to jurisdictional claims in published maps and institutional affiliations.

\section{Author details}

${ }^{1}$ College of Life and Environmental Sciences, Minzu University of China, Beijing 100081, China. ${ }^{2}$ Saving Knowledge, Casilla, 13092 La Paz, Bolivia. ${ }^{3}$ Institute of Botany, Chinese Academy of Sciences, Beijing 100093, China. ${ }^{4}$ Kunming Institute of Botany, Chinese Academy of Sciences, Kunming 650201, China.

Received: 8 November 2017 Accepted: 29 May 2018

Published online: 15 June 2018

\section{References}

1. Lee S, Xiao CJ, Pei SJ. Ethnobotanical survey of medicinal plants at periodic markets of Honghe Prefecture in Yunnan Province, SW China. J Ethnopharmacol. 2008;117(2):362.

2. Işıloğlu M, Yılmaz F, Merdivan M. Concentrations of trace elements in wild edible mushrooms. Food Chem. 2001;73(2):169-75.

3. Kalač $P$, Svoboda LR. A review of trace element concentrations in edible mushrooms. Food Chem. 2000;69(3):273-81.

4. Pei SJ. Ethnobotany. Shanghai: Shanghai Scientific \& Technical Publishers; 2007.

5. Zhao Q. Investigation on the distribution and eco-environment of Cortinarius purpurascens Fr. in Laojun Mountain, Yunnan. J Yunnan Agri Univ. 2007;22(3):412-6. 
6. Lai QK, Chen YF, Xiao-Hua WU, Huang L. Investigation on management and use of wild edible mushroom resources in Yimen County of Yunnan Province. Resour Dev Mark. 2009;25(5):421-4.

7. Shen X. An investigation on the resources of wild edible mushrooms. Ecol Econ. 2002;17(7):60-2.

8. Xu ML, Qu YC, He MQE, Zhang Y, Zhao RL. Investigation on the relationship between wild edible mushroom and farmers income in Yimen County. Edible Fungi China. 2014;33(6):62-6.

9. Song DS. An analysis on the olomestic and abroad markets prospect of wild edible fungi and the position of Yunnan edible fungi. J Southwest Fore Coll. 2002;22(3):412-6.

10. Kupradze I, Jorjadze A, Arabidze A, Beltadze T, Batsatsashvili K, Zambrana NP, Bussmann R. Ethnobiological study of svaneti fungi and lichens: history of research, diversity, local names and traditional use. Am J Environ Prot. 2015;4:101-10

11. Sher H, Aldosari A, Bussmann RW. Morels of Palas Valley, Pakistan: a potential source for generating income and improving livelihoods of mountain communities. Econ Bot. 2015;69(4):345-59.

12. Kasper-Pakosz R, Pietras M, Łuczaj Ł. Wild and native plants and mushrooms sold in the open-air markets of south-eastern Poland. J Ethbobiol Ethnomed. 2016;12(1):45

13. Kang J, Kang Y, Ji X, Guo Q, Jacques G, Pietras M, Łuczaj N, Li D, Łuczaj Ł. Wild food plants and fungi used in the mycophilous Tibetan community of Zhagana (Tewo County, Gansu, China). J Ethbobiol Ethnomed. 2016;12(1):1-13.

14. Kang $Y$, Łuczaj $Ł$, Kang J, Zhang S. Wild food plants and wild edible fungi in two valleys of the Qinling Mountains (Shanxi, central China). J Ethbobiol Ethnomed. 2013;9(1):26.

15. Kang Y, Łuczaj Ł, Kang J, Wang F, Hou J, Guo Q. Wild food plants used by the Tibetans of Gongba Valley (Zhouqu County, Gansu, China). J Ethbobiol Ethnomed. 2014;10(1):20.

16. Wu JC, Lu H. Prospect of wild edible mushrooms industry and suggestions for industry development in Yunnan. J West China Fore Sci. 2006:35(2):154-8.

17. Jonsson $\mathrm{H}$. The mushroom at the end of the world: on the possibility of life in capitalist ruins. Anthropol Q. 2016;90(3):279-81.

18. Robinson BE, Provencher $B$, Lewis DJ. Managing wild resources: institutional choice and the recovery of resource rent in Southwest China. World Dev. 2013;48(8):120-32

19. Mortimer PE, Karunarathna SC, Li Q, et al. Prized edible Asian mushrooms: ecology, conservation and sustainability. Fungal Divers. 2012;56(1):31-47.

20. Yun W, Hall IR. Edible ectomycorrhizal mushrooms: challenges and achievements. Can J Bot. 2004;82(8):1063-73.

21. Luo SY, Xi WJ. Wild mushroom resources and its sustainable utilization in Chuxiong Prefecture. J Chuxiong Normal Univ. 2007;22(3):29-33.

22. Christensen M, Larsen HO. How can collection of wild edible fungi contribute to livelihoods in rural areas of Nepal? Am J Clin Pathol. 2005;113(1):59-63.

23. Arnolds E. Conservation and management of natural populations of edible fungi. Can J Bot. 1995;73(S1):987-98.

24. Zhang Z, Zhang L, Li LQ. Artificial propagation analysis on wild edible fungus in Yimen County. Forestry Construction. 2015:181:33-5.

25. Xin T, Riek JD, Guo H, Jarvis D, Ma L, Long C. Impact of traditional culture on Camellia reticulata in Yunnan, China. J Ethbobiol Ethnomed. 2015;11(1):1-11.

26. Yang YH, Su KM, Wang ZH, Bai HF, Yu Y. Discussion about strategies for management and protection of wild mushroom resources in Chuxiong Prefecture. J West China Fore Sci. 2006;35(4):154-8.

27. Liu A, Pei S, Chen S. Yi nationality's sacred groves and biodiversity conservation in Chuxiong, Yunnan. Chin J Appl Ecol. 2000;11(4):489-92.

28. Liu H, Zhang J, Li T, Shi Y, Wang Y. Mineral element levels in wild edible mushrooms from Yunnan, China. Biol Trace Elem Res. 2012;147(1-3):341-5.

29. Ouzouni PK, Petridis D, Koller WD, Riganakos KA. Nutritional value and metal content of wild edible mushrooms collected from West Macedonia and Epirus, Greece. Food Chem. 2009;115(4):1575-80.

30. Vaz JA, Barros L, Martins A, Santos-Buelga C, Vasconcelos MH, Ferreira ICFR. Chemical composition of wild edible mushrooms and antioxidant properties of their water soluble polysaccharidic and ethanolic fractions. Food Chem. 2011;126(2):610-6.

31. Yi L, Zhang J, Xue Y, Wang Y, Lu Y, Liu Y. The analysis for the nutritional ingredient of wild edible fungus in tourist attraction-taking Yunnan Province as an example. Adv J Food Sci Technol. 2014;6(11):1272.

32. Gan RY, Kuang L, Xu XR, Zhang Y, Xia EQ, Song FL, Li HB. Screening of natural bioactive from traditional Chinese medicinal plants associated with treatment of rheumatic disease. Molecules. 2010;15(9):5988-97.
33. Long CL, Li SM, Long B, Shi Y, Liu BX. Medicinal plants used by the Yi ethnic group: a case study in central Yunnan. J Ethbobiol Ethnomed. 2009:5(1):13.

34. Zhou WY, Yang FW, Zhu MY, Luo YJ, Huang XP. The folk custom of Chuxiong Yi ethnic. [楚雄彞族民俗大观]. Kunming: The Nationalities Publishing House of Yunnan; 2005.

35. Yang CY, Puchi DL. On Yi ethnic groups and its branches. J Bijie Univ. 2009; 2(27):20-2.

36. Yang QG. Chuxiong Yi national minority tradition common people residence and settlement research. Kunming University of Science \& Technology, 2008

37. Mahaibuii, Phonetic and vocabulary research on Suodi dialect of North Yi language-compare with other four dialect, Jinan University, 2015.

38. Liu ZF, Wu XH. Investigation, analysis and recommendations of the circulation market of wild edible fungi in Nanhua County of Yunnan Province. Issues Forest Econ. 2012:32(4):360-3.

39. Wang XH, Liu PG, Yu FQ. Color atlas of wild commercial mushrooms in Yunnan. [云南野生商品蘑菇图鉴]. Kunming: Yunnan Science and Technology Press; 2004.

40. He J. Globalised forest-products: commodification of the Matsutake mushroom in Tibetan villages, Yunnan, Southwest China. Int Forest Rev. 2010;12(1):27-37.

41. Brown M, Mclellan T, Li H, et al. Applied mycology can contribute to sustainable rural livelihoods: building upon China's Matsutake management initiatives. Environ Manag. 2018;61(2):263-74.

42. Liu AZ, Pei SJ, Chen SY. An investigation and study on the plant worship by Yi people in Chuxiong, Yunnan. Chinese Biodivers. 2000;8(1):130-6.

43. Min L, Yu L. New development trend of edible fungus industry in China. Asian Agric Res. 2012;04(1):62-7.

44. Kamalebo HM, Malale HNSW, Ndabaga CM, et al. Uses and importance of wild fungi: traditional knowledge from the Tshopo Province in the Democratic Republic of the Congo. J Ethbobiol Ethnomed. 2018;14(1):13.

45. Bauer Petrovska B, Panov S, Zafirovska DR, Kulevanova S. Electrophoretic study of mushroom proteins. J Food Agric Environ. 2015;2(1):148-52.

46. Falandysz J, Zhang J, Wang YZ, Saba M, Krasińska G, Wiejak A, Li T. Evaluation of mercury contamination in fungi boletus species from latosols, lateritic red earths, and red and yellow earths in the circum-Pacific mercuriferous belt of southwestern China. PLoS One. 2015:10(11):e0143608.

47. Dentinger BT, Suz M. What's for dinner?: undescribed species in commercial Porcini from China. PeerJ. 2014;2:e570.

48. Tsai SY, Tsai HL, Mau JL. Antioxidant properties of Agaricus blazei, Agrocybe cylindracea, and Boletus edulis. LWT Food Sci Technol. 2007:40(8):1392-402.

49. Hall IR, Lyon AJE, Wang Y, Sinclair L. Ectomycorrhizal fungi with edible fruiting bodies 2. Boletus edulis. Econ Bot. 1998;52(1):44-56.

50. Pachlewski R, Strzelczyk E, Kermen J. Studies of Cantharellus cibarius Fr. a mycorrhizal fungus of pine and spruce. Acta Mycol. 1996;31(2):143-50.

51. Strzelczyk E, Dahm H, Pachlewski R, Rózycki H. Production of indole compounds by the ectomycorrhizal fungus Cantharellus cibarius Fr. Pedobiologia. 1997:41(5):402-11.

52. Zheng S, Wang H, Zhang G. A novel alkaline protease from wild edible mushroom Termitomyces albuminosus. Acta Biochim Pol. 2011:58(2):269-73.

53. Skelton GS, Matanganyidze C. Detection by quantitative assay of various enzymes in the edible mushroom Termitomyces microcarpus (Berkley et Broom) Heim. Bulletin De La Société Botanique De France. Lettres Botaniques. 2014;128(3):143-9.

54. Wang MX, Wang W, Wang WY. Studies on optimization technology of submerged fermentation for Morehella esculenta. Packag Food Machinery. 2014:32(1):15-8.

55. Bei L, Rui WS, Bo H, Xiang G, Lan S, Ying ZL. Nutrient analysis of Morchella angusticeps Peck. Food Sci Technol. 2011;7:65-6.

56. Trev N. Phallus indusiatus. Lect: Lect Publishing: 2012.

57. Nadaroglu H, Tasgin E. Purification and characterisation of laccase from Lactarius volemus and its application in removal of phenolic compounds from fruit juice. J Food Agric Environ. 2013;11(3):109-14.

58. Huang $X$, Liu Y, Zhang L. Antagonistic effect of Russula virescens (Schaeff.) Fr. against Bortrytis cinerea. J Agr Sci Tech-Iran. 2012;13(3):669-71.

59. Joshi S, Joshi S. The current status of the family Russulaceae in the Uttarakhand Himalaya, India. Mycosphere. 2012;3(3):486-501.

60. Song Z, Jia LF. Characteristics of Se-enriched mycelia by Stropharia rugoso-annulata and its antioxidant activities in vivo. Biol Trace Elem Res. 2009;131(1):81-9.

61. Hwang SK, Kim JG. Nucleotide sequence analysis of the 5 s ribosomal RNA gene of the mushroom Tricholoma matsutake. J Microbiol. 2000:33(2):136-41. 